\title{
Peak performance: collaborative crisis management before and during international summits ${ }^{1}$
}

\section{Sanneke Kuipers*}

Faculty of Governance and Global Affairs, Leiden University, 2501EE The Hague, The Netherlands Email: s.l.kuipers@fgga.leidenuniv.nl ${ }^{*}$ Corresponding author

\section{Marij Swinkels}

\author{
Utrecht School of Governance, \\ Utrecht University, \\ Bijlhouwerstraat 6, \\ 3511ZC Utrecht, The Netherlands \\ Email: e.m.swinkels@uu.nl
}

\begin{abstract}
This comparative case study probes into conditions for collaborative governance in the security organisation of international summits. The security of Summits can be seen as a latent crisis, for which collaboration amongst a variety of stakeholders is necessary. Managing collaboration in preparation for latent crises is the focus of this paper. The case studies (the Nuclear Security Summit in The Hague in 2014 and the G20 in Toronto in 2010) reveal the importance of: inclusion of a diversity of relevant actors; symmetry of power and resources among actors; the outreach and legitimisation by network leaders; positive steps to repair antagonism between network partners and opposition against the Summit; and the commitment of stakeholders to make the collaboration work. These findings highlight the importance of collaborative crisis management in preparing for and managing high profile security events.
\end{abstract}

Keywords: collaborative governance; summits; crisis management; security management; networks; coordination.

Reference to this paper should be made as follows: Kuipers, S. and Swinkels, M. (xxxx) 'Peak performance: collaborative crisis management before and during international summits', Int. J. Emergency Management, Vol. $\mathrm{x}$, No. x, pp.xxx-xxx.

Biographical notes: Sanneke Kuipers is an Associate Professor at Leiden University's Institute of Security and Global Affairs in The Hague and senior researcher-advisor at Crisisplan $\mathrm{BV}$, an international crisis management consultancy firm based in the Netherlands. She teaches and publishes on postcrisis blaming and accountability, transboundary crises, organisational crises and on institutional development of public organisations. She is the Chief Editor of the journal Risk, Hazards and Crisis in Public Policy (Wiley) and an Associate Editor of the Oxford Research Encyclopedia of Crisis Analysis (Oxford University Press). 
Marij Swinkels is a $\mathrm{PhD}$ candidate and a Lecturer at the Utrecht School of Governance, Utrecht University. Her dissertation focuses on the role and influence of political leaders and their economic ideas in the Eurozone crisis. She teaches courses in political leadership, policy analysis and public administration. Furthermore, she founded a project to increase access to higher education for refugee students at Utrecht University.

\section{Introduction}

When world leaders meet, the stakes are high - both in terms of policy outcomes and in terms of security around the event. We live in an era of 'Summits' as international Summits are held ever more frequent. In fact, international summits have become the most common expression for global governance (Bradford et al., 2008), representing political controversy and potential global agreement simultaneously. G8 and G20 Summits are held yearly since 2008. Regional summits (EU for instance), Climate conferences, Information society summits, IMF/World Bank meetings and more classical diplomacy events such as Nuclear Security summits (Washington, Seoul, The Hague) are also on the rise.

By nature, these events invite demonstrations and protestors, who seek global media attention for their issues and attempt to influence negotiations between political leaders. Norris et al. (2005) report a rise in demonstration activism since the 1970s. Their comparative study shows that activism in 1999-2001 scores almost twice as high in some European countries (Belgium, France, Italy, the Netherlands) compared to the US and Canada (p.199). Though local and national approaches to demonstrations differ, these countries have similar constitutional rights in place for citizens to express their disagreement with government policy publicly and collectively. Meanwhile, activists have become increasingly mobile, crossing geographical and physical borders (D'Arcus, 2006). It follows that (potentially violent) protests must be anticipated prior to and during Summits.

Summits, therefore, qualify as high-security events: the presence of so many political leaders, as well as the expected activism and demonstrations, require extreme security measures. Meanwhile, the host country needs to organise for successful negotiations in a comfortable atmosphere, respect civil rights of protestors, arrange for the complex logistics and accommodation of international delegations, and limit the consequences in terms of restrictions for its own citizens.

When the European Council decided in 1997 to meet in Gothenburg in 2001, longterm preparations had been possible. Swedish policy makers decided to invest in an 'open atmosphere' during the summit in Gothenburg (SOU, 2002, p.275). Despite violent protests during previous summits in Prague, Nice and Malmö, ${ }^{2}$ Gothenburg police authorities saw no need to learn from their French and Czech colleagues because the Swedish approach would be fundamentally different (SOU, 2002: 122, p.367). The Swedish model was based on mutual respect and dialogue between authorities and demonstrators. Triggered by rumours on violent activists among the demonstrators, the police decided on the day before the summit to increase security measures and lock 650 demonstrators inside the school where they resided. When confrontations escalated in the streets, police authorities lacked the manpower to control the situation. The next day, 
the police even used firearms against the demonstrators and severely wounded one demonstrator. The police forcefully arrested hundreds of demonstrators and 86 demonstrators required medical treatment in local hospitals (Wallmann, 2006). One month later, the Genoa G8 in July 2001 provided another example of a Summit ending violently with the death of anti-globalisation protestor Carlo Giuliani. Also more recently, during the G20 Summit in Hamburg, July 2017, the charming downtown old harbour area turned into a battlefield.

Why do some Summits end in chaos whereas others go by calmly? It seems appealing to attribute riots and violence to operational failure, fanatic protesters or political context. Yet incident evaluations after Gothenburg, Nice, Genoa and Prague pointed to organizational factors such as the lack of communication between police forces, the lack of clarity considering responsibilities and mandates between network partners, blind spots and hubris on behalf of responsible authorities, and limited (inter)national and interorganisational learning in the preparation phase (Cf. Hansén and Hagström, 2004; SOU, 2002: 122; Wallmann, 2006; KAMEDO, 2001).

The findings from the Swedish, French, Italian, and Czech evaluators suggest that network governance in the preparation phase may offer key insights to how collaborative networks produce the desired security outcome in latent crises such as Summits. Threat, urgency and uncertainty are crisis characteristics (see Rosenthal et al., 1999; cf. Boin et al., 2017) that apply to Summits and make them 'latent crises', and as such special cases for collaboration. In a context of continuous threats, pressing deadlines and conflicting interests, decision makers from various backgrounds have to cooperate to provide public safety and reliability of critical infrastructures under conditions of high uncertainty.

As Summits occur regularly, they seem more comparable than other types of crises. Authorities can carefully prepare, as Summits have a lead time. They provide an opportunity for learning, as next Summits are scheduled before the current one is over. We can study the conditions for collaboration in relation to security outcomes, as detailed evaluations of all preparations provide rich material for comparative case studies. The aim of this paper is to explore the value of collaborative governance insights in a comparative case study on security of Summits. In the next section, we will present a framework for the analysis of collaborative governance in a crisis management setting.

\section{Theory}

\subsection{Setting the scene for collaboration}

Public policymaking and its implementation involve several actors because public problems are usually multi-dimensional and authority is dispersed over several actors in a non-hierarchical network. Hence, public administration scholars have extensively studied in recent years how these actors collaborate in networks. Collaborative governance equals "the process of facilitating and operating in multi-organisational arrangements to solve problems that cannot be solved (...) by single organisations" (Agranoff and McGuire, 2003, p.4).

The challenges of collaborative governance increase when set apart from day-to-day routines, when public problems have to be dealt with under conditions of threat, urgency and uncertainty (Boin et al., 2017). This is the case in crises that our governments should 
prevent from happening and respond to when they still occur. In doing so, authorities increasingly have to collaborate in networks. These networks involve several levels of governance, both public and private actors, complex hierarchical relations, and both routine and ad hoc cooperation partners (Grunwald and Bearman, 2017; Lee and Fleming, 2015; Redshaw et al., 2015). Therefore, according to Nohrstedt et al. (2014), initiators of networked crisis governance should:

- anticipate which actors will be involved in crisis response operations and what their repertoires contain

- ensure that managers are capable to collaborate when a crisis occurs

- institutionalise inter-organisational solutions enabling swift mobilisation of networks.

Collaboration in networks has received relatively little attention in crisis research so far (Kuipers and Welsh, 2017). While cooperation features in crisis research, it is usually understood as an ad hoc phenomenon when independent actors suddenly have joint responsibilities in managing a particular crisis. Collaboration differs from cooperation in crisis in two important aspects. First, collaboration is more structural than cooperation. Though crisis partners and contexts may differ from time to time, patterns of interaction are similar. Collaborative governance involves long-term cooperation between organisations with a stake in public policy implementation and its outcomes (O'Leary and Bingham, 2009). A recurrent diagnosis of investigations studying crisis response is that coordination between cooperating actors involved was absent (Boin and Bynander, 2014). Second, collaboration implies working together towards a shared goal. Agranoff and McGuire (2003, p.4) assert that collaboration assumes reciprocity. Actors have something to win by collaborating: without it, the desired outcome of policy implementation is less likely to occur. However, crisis and security settings can compromise shared interests: partners involved usually do have a shared objective (such as the desire to help citizens in need, or to provide their services without overlap), but also deeply conflicting interests (e.g. some have a stake in sharing information on victims, others have not - for privacy or prosecution reasons).

\subsection{Summits as crises}

Seen from a crisis perspective, Summits are latent crises that put collaboration under pressure, in advance. In Summits as latent crises, uncertainty stems from the diversity of risks involved in protecting heads of state, managing crowds and protests, and securing an area against terrorist attacks. The urgency of operations results from pressing deadlines and the peak performance required at the upcoming moment of truth. Also, Summits involve threat because events can go dramatically wrong - as described in the introduction.

Seen from an event-management perspective one could see Summits as 'liminal' events, i.e., "set apart from day-to-day routines when the explicit and implicit goals that governed the everyday utilisation of public space and social interaction in the host towns are accepted or transgressed" (Boersma, 2013, p.107, citing Van Heerden, 2011, p.65). This event characterisation allows for unique temporary measures, novel ideas of what is appropriate, an experience of togetherness among actors and adjustment of power constellations to overcome structural constraints (Boersma, 2013, p.108). 
In sum, Summits are not business as usual. Summits are major events that require crisis-like preparation in a collaborative network. Meanwhile, Summits have such an exceptional character in terms of event management that they have structural implications for the next event. The conditions for collaborative governance formulated by Ansell and Gash (2008) offer key insights for the organisation and outcome of highly securitised Summits. The project organisations involved in preparing for both Summits meet the criteria above for defining a network arrangement as collaborative governance. In addition, the crisis characteristics uncertainty, urgency and threat do not so much alter, but instead magnify the tensions involved in power asymmetries, interdependence, antagonism or distrust that seem to be characteristic of collaborative networks such as those combatting persisting policy problems such as unemployment or juvenile crime at the local level (see Ansell and Gash, 2008, for more examples).

\subsection{Conditions for collaborative crisis management}

If collaboration failure is a recurrent problem in crisis response, we need to look at the conditions for successful collaborative crisis governance. Ansell and Gash (2008) provide such conditions in their review study of 137 collaborative governance cases. They define collaborative governance as a "government arrangement where one or more public agencies directly engage non-state stakeholders in a collective decision-making process that is formal, consensus-oriented and deliberative and that aims to make or implement public policy or manage public programs or assets" (p.544). They formulate six criteria for defining a network arrangement as collaborative governance:

- the network is initiated by public agencies or institutions

- the network includes non-state actors

- participants engage directly in decision making

- the network is formally organised and meets collectively

- the network aims to decide by consensus

- the focus is on public policy or public management.

Preparing for Summits is a public task, where public institutions are responsible for the security organisation. Crisis management does often but not always involve non-state actors. Actors do always vary in size, resources, mandate, etc., with similar implications as public-private tensions. Because of the sense of urgency and nature of the crisis, the networked form of crisis decision-making between several actors is not per se driven to produce a consensus between all partners on all decisions, and they do not always meet collectively. Yet conditions for successful collaboration may be similar. The desire for mutual agreement seems to dominate because authorities that disagree also assume responsibility for costs of alternatives and they shape precedents for future cooperation. In essence, the networked governance of crisis does often lack a central direction, with non-hierarchical partners that need each other but do not have authority over each other.

Ansell and Gash's (2008) model includes three broad categories of conditions for collaborative governance: starting conditions, institutional design, and facilitating leadership. The conditions that may help or hinder collaborative governance will be discussed per category below. 


\subsection{Starting conditions}

Three starting conditions have a crucial impact. First, a power asymmetry implies that collaborative governance requires positive efforts within the network to empower the representation of disadvantaged actors. Second, collaborative governance will only work if there is some degree of interdependence. If actors can pursue their goals unilaterally, incentives to commit to network collaboration are undermined. Third, a prehistory of antagonism among participating actors in the network impedes later collaborations, as much as previously gained mutual trust will help to make a collaborative governance project successful (Ansell and Gash, 2008, pp.551-553).

\subsection{Facilitative leadership}

Ansell and Gash (2008, p.554) claim that leaders facilitate collaboration by steering the network 'through the rough patches of the collaborative process'. They identify two different leadership roles: the honest broker and the organic leader. A leading person within the network, accepted by the respective stakeholders, can assume the role of a broker when power distribution is relatively equal and incentives to cooperate are high among actors involved (2008, p.554). When the power distribution is more asymmetric or incentives to participants are weak, then collaborative governance is more likely to succeed if there is a strong 'organic' leader who commands the respect and trust of the various stakeholders at the outset of the process (2008, p.555).

\subsection{Institutional design}

Institutional design includes the basic protocols for collaboration, such as network access and how the network participants actually get together. According to Ansell and Gash (2008; cf. Reilly, 2001) exclusion of key stakeholders is a critical reason for failure. Also, proximity and frequent face to face contact between actors in the collaborative network can be crucial (though not sufficient) for the process of building trust, mutual respect, shared understanding and commitment (2008, pp.555-556).

This study applies theory on networked governance to Summits as cases of collaboration in crisis and security settings. Theories on these type of events, whether defined as latent crises or liminal events, imply that the situation can bring out both the best and the worst in the actors involved. They underline the idea that Summits are occasions that magnify the potential tensions and incentives for cooperation in collaborative networks.

\section{Research design and methods}

Our two cases involve the wide spectrum of security-related actors, both representatives from sectors affected by security measures and sectors facilitating security measures. We do not study the diplomatic outcome of the cases nor did we study operational and tactical decisions during the summits. The selected Summits are similar in terms of political controversy, terrorist threat and location (metropolitan areas), but they differ in 
perceived outcome. One summit was - in spite of intense network cooperation perceived as a security drama, a civil rights nightmare and a logistical standstill (G20, Toronto), and another summit ran smoothly in civil rights, logistics and security terms (NSS, The Hague). This allows us to explore conditions for successful collaborative practices between different stakeholders in each case.

Our qualitative comparative case study probes into whether collaboration in the networks responsible for security and logistics before and during the Summits reveals striking differences that may relate to the diverging case outcomes of the two summits. We assess if the above conditions were present in the cases, and how these conditions relate to the overall outcomes of the cases. We formulated a set of questions that we used to structure the in-depth interviews with key stakeholders. In total, we held 25 interviews with key partners in the organisation of the Summits, in addition to desk research. We developed an intricate coding scheme to document, code and categorise interview results in Nvivo for the sake of systematic comparability and pattern-finding. In total 14 'nodes' (main codes) and 57 sub codes gave detailed guidance to our coding. After a pilot, the coders jointly reviewed the coding scheme. Both researchers hand-coded all interviews and discussed the results to ensure identical understanding of the codes.

The outcomes of collaboration in the security management of a Summit are compared on a variety of dimensions such as security, public order, civil rights and mobility. It is important to take into account all these dimensions, because collaborating actors may have conflicting interests with regard to disregarding constitutional rights (for instance when all protests and demonstrators are banned from the wider area surrounding the Summit) or restricting all local mobility. Vice-versa, if both citizen rights and their mobility have to be respected, the risks that violence can disturb the Summit are much higher.

\section{NSS the Hague vs. G20 Toronto: key characteristics}

We will argue that both the G20 summit and the NSS summit were highly similar in terms of scope and setting (see Table 1 for the key security settings for both events), but led to different outcomes in terms of experienced unrest (Table 2).

As is shown in Table 1, the Summit in Toronto, Canada, in June 2010 was the fourth G20 meeting to discuss global finance and economy. Its theme 'Recovery and New Beginnings' referred to the anticipated stimulus to overcome the ongoing economic worldwide recession. The G20 was combined with a G20 held immediately prior to the G20 in nearby rural Huntsville. Together, the Summits represented the largest and most expensive security operation in Canadian history. They were criticised for being many times more costly than similar events in the UK and in Japan (Chase, 2010).

The NSS 2014 was the third in a row, preceded by the NSS in Washington (2010) and Seoul (2012). Though the aim of the Summits was to improve global nuclear safety, the NSS in Seoul had sparked off violent protests. The NSS in The Hague was combined with a G7 in the same city, which gave it a global economic dimension as well. In both events, over 20,000 security officers were deployed from a variety of policing organisations during the operation, a part of the city centre was entirely sealed off with fences and the Summits paralysed regional logistics for three consecutive days.
AQ1: Please check if the correction carried out in the highlighted sentence is ok. 
Table 1 Characteristics of the high-security events

\begin{tabular}{|c|c|c|}
\hline & $N S S$ & G20 \\
\hline Theme & $\begin{array}{l}\text { Strengthening Global Nuclear } \\
\text { Security }\end{array}$ & $\begin{array}{l}\text { Economic recovery after the } \\
\text { economic recession }\end{array}$ \\
\hline Dates & 26-27 June, 2010 & 24-25 March, 2014 \\
\hline Occurrence & Third edition & Fourth edition \\
\hline Back-to-back event & Combined with G7 & Combined with G8 \\
\hline Summit organisation & $\begin{array}{l}\text { Project team Security and Safety, } \\
17 \text { members from different security } \\
\text { domains and different public and } \\
\text { private organisations }{ }^{1}\end{array}$ & $\begin{array}{l}\text { TPS, RCMP, PRP, OPP, } \\
\text { CF, } \mathrm{SMO}^{2}\end{array}$ \\
\hline Security staff employed & $+/-21.000$ & $+/-20.000$ \\
\hline Number of delegations & 58 & 36 \\
\hline Security zones & $\begin{array}{l}5 \text { security rings: first and second up } \\
\text { to } 250 \mathrm{~m} \text { range around conference } \\
\text { centre }\end{array}$ & $\begin{array}{l}\text { Inner and outer zones. Inner } \\
\text { zone: } 3-4 \mathrm{~km}^{2}\end{array}$ \\
\hline $\begin{array}{l}\text { High-security measures in } \\
\text { inner security zone }\end{array}$ & $\begin{array}{l}\text { 'Ring of steel': high fences, police } \\
\text { control, CCTV systems }\end{array}$ & $\begin{array}{l}3 \text { meter high fences, LRAD- } \\
\text { devices, }{ }^{3} \text { mobility } \\
\text { restrictions through } \\
\text { Regulation } 233 / 10 \text {, Public } \\
\text { Works Protection Act, Stop } \\
\text { and Search }\end{array}$ \\
\hline
\end{tabular}

${ }^{T}$ These include but are not limited to: National Coordinator for Terrorism and Security, National Police, Municipality The Hague, Ministry of Infrastructure and Environment, Ministry of Defense, Ministry of Foreign Affairs, Ministry of Internal Affairs, Prorail (train network), Border Police (KMAR), hotels, etc.

${ }^{2}$ Toronto Police Services, Royal Canadian Mounted Police, Peel Regional Police, Ontario Provincial Police, Canadian Forces, Summit Management Office

${ }^{3}$ A Long Range Acoustic Device (LRAD) is a hailing device that sends loud warning tones over longer distances, in this case, deployed to prevent people from standing close to the fences around the secured zone.

Table 2 outcomes in terms of experienced unrest

\begin{tabular}{lcr}
\hline & NSS & G20 \\
\hline Number of protesters & $+/-800$ & 9000 \\
Number of reported incidents & 7 & 600 \\
Number of arrests & 75 & 1100 \\
Number of injured security personnel & 19 & 75 \\
\hline
\end{tabular}

In both cases, interviewees and evaluations indicated that the summit organisation stretched the organisational capacity of security actors and financial resources:

"This summit was the biggest security operation in the history of the Dutch police." (Interviewee The Hague Municipality)

"The NSS provided The Netherlands with the largest mobility operation ever. In order for the transport between Schiphol and The Hague to be safe and 
undisturbed, it was necessary to realise a large number of road cuts and other traffic measures." (Van den Berg and Westerbeek, 2014: 8)

"The hosting of two world summits consecutively from June $25-27,2010$ was unprecedented." (RCMP, 2014)

Thus, the two cases are highly comparable as they

- were preceded by similar Summits that instigated violent demonstrations

- were organised back-to-back with another big summit

- were organised in a densely populated city centre

- put similar demands on policing and operational capacity.

Furthermore, both events occurred in the post $9 / 11$ era, in which security measures have become rather extreme in order to provide safe and secure events (see e.g., Graham, 2011). The use of fenced off inner security zones, the use of obscure laws such as Public Works Protection Act -allowing police to arbitrarily detain, search and arrest people on site - and the use of LRAD-devices are cases in point. This all took place against the backdrop of increased media scrutiny and the demands of citizens that such events do not disturb day-to-day life, leading to the challenge how to balance security and mobility. The contextual conditions for both conferences were highly similar. However, in terms of experienced unrest, the results are strikingly different.

As Table 2 shows, the Toronto Summit attracted 9000 protesters and resulted in over 600 reported incidents and over thousand arrests, whereas The Hague Summit passed by rather peacefully with a little under 800 protesters and 7 reported incidents. The protests in downtown Toronto addressed generic issues as globalisation, capitalism, gay rights, and further escalated during the summit itself. What started off as peaceful demonstrations, led to an increase in protesters and the use of black bloc tactics. ${ }^{3}$ Shops and businesses in downtown Toronto were molested. In total, more than 1100 people were arrested during the week of the summit. Riot police used tear gas and plastic bullets to push back the protesters. ${ }^{4}$

Now, one could simply argue that these outcomes are a matter of bad luck or a capital bias as some cities seem more attractive to protestors. However, in terms of expected activism, The Netherlands scores higher than Canada in studies on protest demonstrations and activism, with self-reported activism among respondents scoring $32 \%$ in the Netherlands (ranking 3rd which is comparable to Sweden ranking 2nd with 35\%) against $19 \%$ in Canada (14th in rank which is more comparable to South Korean scores $14 \%$, ranking 18th) (Norris et al., 2005, p.199). In other studies, Sweden and the Netherlands score comparably again, but now in the middle range of national protest cultures (Torcal et al., 2016 - the study does not include Canada). Given the potential of international mobilisation to the location of an event, national protest cultures are perhaps only of relative importance.

\subsection{Toronto G20 course of events}

When the Harper administration announced in June 2008 that the next G8 summit would be held on 25 and 26 June, 2010 in Huntsville, Ontario, the Royal Canadian Mounted Police (RCMP) assumed general responsibility for the security of the event. Planning for the event started with Chief Superintendent Alphonse MacNeil in the lead. Five different 
police forces were represented in the G8 steering committee and partnered in the Integrated Security Unit (ISU) relatively smoothly. ${ }^{5}$

In December 2009, the Harper administration announced that the G8 summit would be held back to back with a G20 summit in downtown Toronto on June 26 and June 27, 2010. In February 2010, they announced the venue: The Metro Toronto Convention Centre (MTCC) in the downtown financial district. "This news changed everything" (TPS interviewee). The TPS suddenly became a lead agency because the city of Toronto became the primary event location. Confusion reigned on the role of TPS, RCMP and the other partners, yet no formal changes were made regarding the overall responsibility for the security of the event. The prime ministers' office (Privy Council Office) set up a Summit Management Office (SMO), responsible for the organisation of the G20 Summit and for coordination among federal agencies. The RCMP, as the lead law enforcement agency at the federal level, was responsible for the overall security of both the G8 and G20 summits. Information from the prime ministers' office went to the RCMP and then down to the other partners. In the network, information was not shared easily among security partners. Furthermore, the fact that the summits were held back to back hindered the mobilisation and deployment of staff needed in both Huntsville and Toronto.

The Harper administration's late announcement of the G20 summit left authorities with only four months to plan the G20. As a result, planning was rushed, information was inadequate and time for training and preparing operational staff was lacking. The RCMP was responsible for the security of all political leaders and took over the jurisdiction of downtown Toronto. ${ }^{6}$ The overarching goal of the RCMP was to organise a 'safe and secure summit for the delegations' (RCMP interviewee). The RCMP closed off the Summit's security zones so the Summit could be held in peace, but the security operation severely disrupted city life in Toronto (OIPRD, 2012). Businesses were temporarily closed, public transport was disrupted and major thoroughfares were closed.

The TPS controlled the outer zones within the city. In these zones, public order issues unfolded resulting in violent protests and riots starting on June 26. The TPS officers in these zones received support from OPP and RCMP officers who operated under the command of the TPS. The riots escalated to a point that individual TPS chief commanders decided to 'take back the streets'. The use of force between police and protestors further escalated, leading to a circle of 'violence to be met with violence' (OIPRD, 2012). Several independent inquiries report that the G20 policing operations resulted in severe human rights violations.

Media reports paid little attention to the content of the summit. Instead, they reported on the high-security fences, massive police presence, large groups of protesters employing 'black block' tactics, vandalism and excessive violence between police and protestors. Yet most police respondents assert that, given the scope of the security operation, the different police jurisdictions involved, and the short notice, policing was carried out very well.

\subsection{The Hague NSS course of events}

When the Netherlands agreed in 2012 to host the third global Nuclear Security Summit in March 2014, The Hague won the bid as hosting city. The Hague is the Dutch government residence and promotes itself as a city of peace because important international institutions reside in the city. The Dutch Ministry of Foreign Affairs, the primary responsible government department, would organise the event in close cooperation with 
the city (also as its contractor) and local and national security partners. From the start, the overarching goal of organising the NSS was to host a 'dignified, secure and peaceful Summit'. The impact of this three-day high security, high profile event in the most densely populated area of the country on mobility and business continuity was unparalleled.

A Ministerial committee including the PM (chair), the Ministers of Foreign Affairs, Security and Justice, Economic Affairs, Defence, and Infrastructure plus the National Coordinator for Counterterrorism and Security and the Mayor of The Hague formed the ultimate decision unit at the highest strategic level. One level below, responsibility was divided between two committees at the Directorate-General level (one for content/diplomacy and one for the security of the event). Two levels below three project groups (Sherpa team, NSS project team and the Security Project group - PGV) formed the administrative backbone of the event organisation, coordinating the work at the operational level. Diplomacy and security were the two pillars of the event organisation.

The Summit was successful in the eyes of the organisers, and well-received by the Dutch press and international media. No major incidents occurred, only 63 public order disturbance arrests were made and demonstrations passed by calmly. ${ }^{7}$ The Dutch government concluded that its goals were met as the Summit could be characterised as dignified, secure and peaceful.

\section{Analysis}

Below we will highlight the most striking differences in our analysis of factors and conditions that seemed to relate to the different outcomes of the events.

\subsection{Power a-symmetries: broad representation}

For the Toronto G20 Summit, several police respondents said their overarching goal was 'to get heads of state in and out of the Summit safely' which illustrates the isolation of security planning in the Canadian case. Their goal also underlines the perception of the participating actors regarding the focusing event: the time frame clearly ends when the last head of state leaves the Summit. This isolation stands in stark contrast to the integrated, more long-term perspective of the Dutch NSS Summit organisation. From the start, security was but one goal of the entire network of actors responsible for the NSS planning and operations. Security concerns in The Hague had to find a constant balance with the desired peaceful, undisturbed, dignified and festive character of the event, also for the people of the city. Because of this compound aim, societal actors joined the decision-making tables at all governance levels. They brought in different views on how to deal with demonstrations, how to groom public opinion and how to minimise security restrictions that hindered city life and business continuity. Their interests were constantly weighing in on security planning. The Dutch actors adopted this inclusive approach in prior events and their constitutional set up of local autonomy ensured that local demands for a festive and peaceful event were taken into serious consideration.

Though it is unlikely that the exclusion of other interests than security in the Canadian ISU's planning efforts have inspired violent protestors, imposed restrictions, incurred costs and the use of public resources and law enforcement related to the Summit were critically received by the press, leading to a 'them' (Summit/security) against 'us' 
(demonstrators/media/spectators) perspective in media outlets. Though the rogue nature of the protestors and the violence displayed in the city center led $81 \%$ of the Torontonians to conclude in a poll that the police did a good job during the Summit (Chase, 2010), escalation of violence between police and protesters did probably not favourably influence public evaluations of the organisation of the G20 summit.

It seems that the integrated approach in The Hague empowered a diversity of interests. The compound motto ensured that interests that played a minor role in the Toronto G20 planning (citizen mobility, public appreciation for the event), weighed in heavily in the NSS preparations. In that sense, less power-asymmetries between interests involved existed in the Dutch case, also because the Dutch approach took into account that security actors and local stakeholders would have to continue to collaborate after the focusing event. A positive strategy by Dutch authorities to empower all interests of stakeholders in the pursuit of a shared goal, contrasts power/resources imbalances that existed in the Toronto case. In the Toronto case, the crisis characteristics of the event and the ambitions to counter potential security threats at all cost became a magnifier of tensions as suggested in the theoretical introduction.

\subsection{Power a-symmetries: planners vs. operators}

The inclusive, integrated network for preparing the NSS at the strategic and tactical level in the Netherlands was mirrored by a similar network at the operational level. Liaisons present in both networks ensured the operability of decisions taken through information flows and reality checks between the levels, according to respondents. Six months before the NSS would take place, the PGV at the strategic level started losing its grip on the expert groups it had created to work out specific issues. It then seized the opportunity to escalate the most pressing issues to the strategic level and reduce the number of the (45-50) expert groups considerably, to regain oversight and reduce overlap. Respondents saw the lead time (1.5 years) up to the event both as a benefit and a disadvantage: it allowed both for the proliferation of network segments and for the time to 'tame the beast we created'. In any case, sufficient time existed to carefully calibrate strategic and operational plans, practices and responses before and during the event.

Such time was lacking in the Toronto case, in the four months after the Harper administration selected the MTCC venue as the G20 location, to plan and organise operations. In the $\mathrm{G} 8 / \mathrm{G} 20$ preparations phase, an operational network that mirrored the collaborative network of strategic planners existed on paper, but not in practice. Much of the ISU information towards operational forces was directed top down to the chiefs of the operational services and in fact given only a few days prior to the event to the officers involved in the operation. Confusion reigned about the exact plans, strategies and security operations, as operators were not included in the planning dialogue. As one of the lead planners of the G20 recalled in an interview: "I should have ensured that the deputy chief and chiefs of the [operational] services were involved, understood the plans. I did not do that. In the end, the chief was able to say "I didn't know". I learned my lesson there, and if I ever do this again, I would definitely make sure that we were on the same page. Responsibility and accountability were on paper, but that didn't matter. Nobody took that to the chief of police to check if he understood."

Power/resources asymmetries between planners and operators in the G20 case clearly differed from the situation in The Hague as operational actors were not involved in the G20 security planning, hindering collaborative governance and ultimately unsettling 
operations. The security preparations of the planners in Toronto were driven by a hierarchical command and control approach that is not uncommon in traditional crisis and security management operations (Kuipers et al., 2015). By contrast, the NSS preparations involved all the usual crisis and security stakeholders but initiators deliberately refrained from labelling the event a potential crisis and involved representatives from the operational services, as well as the city retailers and residents. This non-crisis approach allowed for more information exchange between stakeholders that reduced potential asymmetries.

\subsection{Incentives to cooperate}

The Hague deliberately competed for the bid to host the NSS in the Netherlands whereas Toronto saw a G20 being imposed on the city by the Canadian federal government. In fact, The Hague had been rather optimistic in its hosting bid, according to respondents. This optimism sometimes complicated the practical organisation when the city had to live up to its promises during preparations. The Foreign Ministry and the City of The Hague had an ambiguous working relation because the city could 'put on two hats'. On the one hand, the city was the subcontractor of the Foreign Office, on the other hand, the city was the ultimate local authority on safety issues. "If they did not wish to do what the Foreign Office wanted them to do, they just put on their 'safety authority hat' and refused to do as instructed because of overriding safety concerns", lamented an official from the Foreign Office. As such, an alternative venue existed for the city to get its way unilaterally. However, respondents asserted that they were so highly interdependent to organise a successful Summit that the city would not push its luck too far.

In contrast, the Toronto city officials who advised against the Harper administration's choice for the Summit location in downtown Toronto, seemed disengaged from further responsibility for the success of the event (The Toronto Star, 2010). The responsibility for security in the conference zone was taken over from the Toronto police by the RCMP with little sensitivity for the social environment.

The choice for the Summit location in downtown Toronto had serious implications for the city. Large security zones, 10-feet high fences, the LRAD-devices ${ }^{8}$ in place, mobility restrictions for all citizens in combination with the adoption of Regulation 233/10 and the active use of the Public Works Protection Act by the Ontario Government, led to a fortification of Toronto's city centre (Ontario Ombudsman, 2010; House of Commons, 2011). Regulation 233/10, enacted in anticipation of the summits, triggered "unusual, even extravagant police powers that could be - and in fact were used to intimidate and arrest people who had done no harm" (Ombudsman Ontario, report December 2010). These measures have contributed to the 'fortress Toronto' image on the newspaper front pages and provoked savage protestors to besiege the area (Della Porta, 2006).

The invited vs. imposed nature of the Summit defined the incentives for participation by key stakeholders in the preparation phase. In The Hague, the city mayor was determined to make this Summit a great success both internationally and locally. Toronto city and the Toronto Police Service had to 'get a job done', a chore that the federal government forced upon them on a downtown location against the advice of the city authorities. The TPS served under the leading authority of the RCMP, a partner who could pursue its security goals unilaterally, in contrast to security stakeholders in the Dutch network who had to deal with a great number of societal representatives. Toronto 
city did not seem as much a partner in the preparations, decision-making and communication about the G20 event as The Hague city was for the NSS, indicating that the Dutch network was more interdependent and less exclusively security-oriented.

\subsection{Trust building and dialogue}

In both Toronto and The Hague, the local police contacted anticipated demonstrators prior to the Summit to explain restrictions, demonstration routes and locations and so on. To anticipate on potential demonstrations and constantly update their threat assessment the Dutch police used international intelligence and cooperation networks to stop potential protestors 'from getting on the bus in Italy' instead of awaiting their arrival more reactively. In the Toronto case, the Joint Intelligence Group (JIG) consisted mainly of personnel from key stakeholders of the ISU the Canadian intelligence service and border agency, Transport Canada and the Canadian Forces. Although official inquiries indicate that "collection and dissemination of intelligence through one central theme supported the partners in working together" they find that "varying protocols and procedures for sharing and classifying information made information sharing difficult" (RCMP, 2014, p.10).

In our study, we did not find clear links to international intelligence and stopping potential protestors at the border in the Toronto case. The Canadian authorities were certainly aware - in the weeks prior to the event - of violent groups moving towards the city. Intelligence information indicated that anarchists using 'Black Bloc' tactics would be present (OIPRD, 2012). Travel alerts issued on June 17 by the US State Department warned US citizens to avoid getting mixed up in demonstrations in Toronto. These alerts did not prevent violent groups from eventually ending up downtown during the Summit. As one respondent noted: "Even with all the intelligence work done, we still did not expect this to happen". In contrast, the Dutch police respondents prided themselves on the rigour of their anticipatory approach.

Diplomats from the Dutch Ministry of Foreign Affairs proactively contacted organised protestors to convince them of the benefits of the NSS in terms of world peace. After all, the Nuclear Security Summit aimed to reduce the risk of criminal or terrorist use of nuclear materials worldwide. Their message: "We are on the same page, who could be against this?". This informal promotion campaign on what NSS was actually about may have contributed to much less fierce anti-nuclear energy protests than for instance during the Seoul NSS of 2012. In the Canadian case, the Community Relations Group (CRG) of the joint police organisations reached out to both citizens affected by the G20 Summit and to potential protesters to facilitate peaceful and lawful protests. Protesters and the CRG did not agree on a comprehensive approach towards the planned demonstrations: "For the most part, there was little positive interaction between the CRG and the more militant activists" (Toronto Police Service, 2011, p.55). The protestors judged the CRG for being solely focussed on obtaining intelligence (Civilian Review and Complaints Commission for the RCMP, 2012).

Because respondents could for security reasons not reveal their threat assessments and the direct result of their intelligence-based security measures, we cannot say whether the Dutch benefited from their proactive, diplomatic approach or from the relative absence of threat in comparison to the Canadian threat assessment and approach. The Dutch respondents assert that their approach reduced the threat substantially in their case, which they considered a valuable lesson learned.

AQ3: Please check if the highlighted reference citation is ok. 
Demonstrators and security actors by nature have a prehistory of conflict rather than cooperation, so collaborative actors need to take steps to remediate low levels of trust. Though the TPS did extensive fieldwork to inform demonstrators, the protesters did not seem to perceive these efforts as a trust-building exercise and the resulting protests do not indicate any positive effects of prior bilateral communication (Ombudsman Ontario, 2011). We found no evidence of specific police trust-building efforts in The Hague. However, the diplomatic approach towards activists by the Dutch Foreign Office as part of an effort to positively communicate on and find agreement and support for the ultimate goals of the Summit seemed to pay off in the sense that it possibly reduced the numbers of organised protesters showing up. From a crisis management perspective, the positive approach can be seen as an important act of meaning-making around a focusing event (that did not alter into a crisis). Meaning-making is a crucial task that can directly influence citizen behaviour and perceptions during an event, according to the crisis management literature (Boin et al., 2017). Such a meaning making effort was essentially lacking in the Toronto approach.

\subsection{Leadership: inwards and outwards}

Though organic leaders emerged in both the G20 and NSS case, leadership in the Toronto case seemed to mainly facilitate cooperation among the police forces. Superintendent MacNeil was portrayed as 'Most Responsible Man in the World' (MacGregor, 2010). Respondents described him as a 'bridge-builder', a facilitator and a person with a 'calming attitude'. He served as an organic leader, facilitating the collaborative process between the police organisations involved. Toronto police respondents characterised their cooperation as smooth, despite a mild historical animosity between the federal RCMP and the local TPS. In the Toronto case, elected City officials, the Ontario government or the Harper administration did not take up a strong mediating role within the network of security stakeholders. The homogeneity of the network - police organisations only - led to wide-shared agreement on their mission (providing security to world leaders and their delegations). Most respondents agreed that, given the difficulties and the time span they had, they successfully pulled off the job at hand.

In the NSS case, leadership emerged at the strategic level (PGV) where leaders facilitated cooperation between the greatest possible variety of network partners, including the city, cabinet departments, business representatives, emergency services, special police forces, intelligence agencies, neighbourhood communities and the military. The chairperson of the PGV was the deputy-DG of the National Coordinator of Counterterrorism and Security in the Netherlands, a Directorate-General that by definition plays a moderating and coordinating role among a diversity of network partners in all its regular activities. This background may have contributed to her coordinating approach and skills, allowing her to become the 'honest broker' in the NSS preparations network.

Furthermore, the mayor of The Hague took up a strong mediating role in coordinating planning efforts of municipalities in the region where escorted transportation would pass and where many of the world leaders were staying in hotels during the Summit. He convinced surrounding municipal authorities of the necessities of the restrictive measures and of the benefits of cooperation. Thereby he gained importance as representative of local interests within the network at the national strategic level. His role could be characterised as an 'organic leader' commanding the respect and trust of his colleague
AQ4: Please clarify if the highlighted reference citation should be removed. 
mayors. In sum, not so much the style of leadership differed between leaders in the Toronto and The Hague cases, but the direction. Leadership in the Dutch case was characterised by outreach and in Toronto by introspective team building efforts.

\subsection{Proximity and face to face contact}

During the G8 and the G20, the strategic decision makers regarding overall public order resided at the Unified Command Centre (UCC) in Barrie, Ontario. The Toronto area command centre (TACC) was located at Pearson's international airport. The UCC was responsible for the overall command and control during the summit. The UCC and TACC were jointly responsible for the inner security zones. The TPS's Major Incident Command Centre (MICC), responsible for public order in the city and located in the city centre was not initially included in the G20 plans. Different police actors led the different command centres (RCMP in Summit zone, TPS in the city of Toronto, RCMP in the region).

Though TPS and RCMP police forces had to work together in the city centre, the extra layer of command created confusion among ground officers (RCMP, 2012). The ISU headquarters (led by RCMP) were in Barrie, remote from the conference site and the MICC. Both command centres report information asymmetries between them during the summit. Amongst the command centres, there was confusion over a shared common operational picture that could have informed the ICU's strategic decisions, for instance, to support the local police outside the Summit zone. Consequently, the TPS were on their own facing violent protestors, taking operational decisions that were later on severely criticised. Nevertheless, the respondents assert that in spite of occasional communication challenges, they were able to operate the motorcades safely and provide the security to the visiting world leaders (cf. OIPRD, 2012, p.61).

In The Hague, the integration of command centres did not come about easily, six months before the NSS began. The local police demanded to include the local emergency services in the operational command centre on site, i.e., inside the secured zone. The special police forces (such as intervention squads and police intelligence groups, part of the national police) in that command centre, opposed against the presence of civilian actors as it would obstruct information sharing with non-police actors present. Local police escalated this issue because they valued the presence of their trusted local emergency counterparts for an integrated operational approach. Ultimately, the PGV intervened at the strategic level and included the relevant non-security actors in the command centre. According to local respondents, the issue harmed the overall reputation of the police in the eyes of other emergency response organisations, but the resulting integrated command centre worked well during the Summit.

The lack of proximity and close contact affected collaborative governance in the G20 case as different organisations led command centres in different places in the operational phase. In The Hague, the command centre ultimately included all relevant partners involved in both securing world leaders and maintaining public order and safety. Again, the emphasis on other than security aspects led to a more inclusive approach in The Hague and intensified the contact between a diversity of stakeholders. Crisis research has long shown that distance between actors responsible for the response effort has a negative influence on joint performance (Smith, 2000). Interaction suffers from lack of proximity and face to face contact (ibid). The collaborative governance in The Hague benefited from the more intense cooperation between network partners. 


\section{Conclusions}

Though we cannot conclude from the observed differences between the cases that they causally relate to the results in terms of public order during the two Summits, the contrasts are insightful. The absence of scholarly research into such differences and the recurrence of Summits, make this explorative study a valuable effort. We argue that our cases confirm the importance of Ansell and Gash's (2008) collaborative governance conditions that contribute to successful networked governance:

- the inclusion of a diversity of relevant actors

- the symmetry of power and resources, or empowerment of weaker actors to compensate for existing asymmetries

- honest brokers or organic leaders - as long as they include a diversity of interests and reach out to legitimate the collaborative network

- $\quad$ positive steps to repair prior antagonism between network partners and affected interest groups outside the network

- the incentives and commitment of stakeholders to make the collaboration with representatives of conflicting interests work.

In this paper, we expected that the studying Summits as latent crisis contexts would intensify implicit tensions and incentives among network partners that influence their collaboration. Crisis characteristics such as uncertainty, urgency and threat work as a magnifier for challenges, but also motivations, present in any collaborative effort. In Toronto, the crisis approach by police authorities narrowly defined the event and the mission of the collaborative network, with a dominant focus on the security of world leaders during the three days of the Summit. This strategy seems to have increased tension among network partners, and with protestors, city representatives and media. The Dutch downplayed the crisis dimension, allowing for a broader time frame and a more inclusive approach to civil and operational actors, who therefore participated in the information exchange and saw their interests represented in the mission of the collaborative network.

Furthermore, the Dutch authorities seemed aware of the crucial task of meaningmaking in crisis response (Boin et al., 2017). Instead of sending police officers to brief the anticipated protestors, the Dutch Foreign Office stepped in and launched a diplomatic offensive to convince NGOs and activists of their common interest in a peaceful event. The intense and frequent face to face contact between network partners also indicates a commitment to, ultimately, crisis cooperation and a shared awareness of the critical challenges they faced together.

In sum, too much of a crisis approach in terms of centralisation, focus on the most immediate and tangible threat (the security of world leaders) and small group decision making seems to have hindered effective collaborative governance in the preparation of the Toronto Summit. Yet, commitment to shared situation awareness, meaning making efforts and joint responsibility to counter critical threats facilitated the Dutch collaboration.

These findings can guide further research on securing high profile security events through collaboration in governance networks in crisis management settings. Such events 
will always be there. When demonstrators may become more mobile and more militant against authorities in a polarised world, authorities responsible for public order and safety cannot afford to ignore the lessons for collaborative governance in security settings.

\section{References}

Agranoff, R. and McGuire, M. (2003) Collaborative Public Management: New Strategies for Local Governments, Georgetown University Press.

Ansell, C. and Gash, A. (2008) 'Collaborative governance in theory and practice', Journal of Public Administration Research and Theory, Vol. 18, No. 4, pp.543-571.

Boersma, K. (2013) 'Liminal surveillance: an ethnographic control room study during A local event', Surveillance and Society, Vol. 11, Nos. 1-2, pp.106-120.

Boin, A. and Bynander, F. (2014) 'Explaining success and failure in crisis coordination', Geografiska Annaler: Series, A., Physical Geography, Vol. 97, No. 1.

Boin, A.t Hart, P., Stern, E. and Sundelius, B. (2017) The Politics of Crisis Management: Public Leadership Under Pressure, Cambridge, New York.

Bradford, C., Linn, J.F. and Martin, P. (2008) Global Governance Breakthrough: The G20 Summit and the Future Agenda, Brookings Institution. Retrieved 1 August, 2014, from https://www.brookings.edu/research/global-governance-breakthrough-the-g20-summit-andthe-future-agenda/

Chase, S. (2010) G8/G20 Security Bill to Approach \$1-billion, Retrieved 3 August, 2016, from http://www.theglobeandmail.com/news/world/g8g20-security-bill-to-approach-1-billion/ article1211436/ retrieved 2015-11-11.

Civilian Review and Complaints Commission for the RCMP (2012) Public Interest Investigation into RCMP Member Conduct Related to the 2010 G8 and G20 Summits, 15 May, Retrieved 5 May, 2015, from https://www.crcc-ccetp.gc.ca/pdf/g8g20R-eng.pdf

D’Arcus, B. (2006) Boundaries of Dissent: Protests and State Power in the Media Age, Routledge, New York.

Della Porta, D. (2006) Social Movements, Political Violence, and the State: A Comparative Analysis of Italy and Germany, Cambridge University Press.

Graham, S. (2011) Cities under Siege: The New Military Urbanism, Verso, London.

Grunwald, J. and Bearman, C. (2017) 'Identifying and resolving coordinated decision making breakdowns in emergency management', International Journal of Emergency Management, Vol. 13, No. 1, pp.68-86.

Hansén, D. and Hagström, A.Z. (2004) I krisen prövas ordningsmakten: Sex fallstudier av extraordinära händelser där det svenska rättssamhället har satts på prov, CRISMART.

KAMEDO (2001) EU-toppmötet i Göteborg 2001 KAMEDO-rapport, Vol. 83, Retrieved 5 May, 2016, from http://www.socialstyrelsen.se/publikationer2004/2004-123-30

Kuipers, S., Boin, A., Bossong, R. and Hegemann, H. (2015) 'Building joint crisis management capacity? comparing civil security systems in 22 European countries', Risks, Hazards and Crisis in Public Policy, Vol. 6, No. 1, pp.1-21.

Kuipers, S.L. and Welsh, N.H. (2017) 'Taxonomy of the crisis and disaster literature: themes and types in 34 years of research', Risk, Hazards and Crisis in Public Policy, Vol. 8, No. 4, early view online.

Lee, S. and Fleming, R.T. (2015) 'Collaborative disaster management in local governments: perception, performance and challenges', International Journal of Emergency Management, Vol. 11, No. 4, pp.343-355.

MacGregor (2010) Phonse' can't Promise Happy Days in Huntsville, Retrieved 29 August, 2015 from http://www.theglobeandmail.com/news/world/phonse-cant-promise-happy-days-inhuntsville/article4388809/ 
Nohrstedt, D., Bynander, F. and Parker, C. and 't Hart, P. (2014) 'Collaborative crisis management: an agenda for research on interorganizational responses to extreme events', Paper presented at the American Political Science Association, 28-31 August, Washington DC, USA.

Norris, P., Walgrave, S. and Van Aelst, P. (2005) 'Who demonstrates? antistate rebels, conventional participants, or everyone?', Comparative Politics, pp.189-205.

O'Leary, R. and Bingham, L. (Eds.) (2009) The Collaborative Public Manager, Georgetown University Press, Washington DC.

OIPRD (2012) Policing the Right to Protest, Retrieved 5 May, 2015, from http://www.oiprd.on.ca/ EN/PDFs/G20-Systemic-Review-2012_E.pdf

Ombudsman Ontario (2010) Caught in the act: Investigation into The Ministry of Community Safety and Correctional Services' Conduct in Relation to Ontario Regulation 233/10 under the Public Works Protection Act, December, Retrieved 5 May, 2015, from https://www.ombudsman.on.ca/Ombudsman/files/58/581252d9-1809-4291-831b88e9adb480c5.pdf

Redshaw, S., Ingham, V. and Loftus, S. (2015) 'Emergency decision making: an exploration of tensions between communities of practice', International Journal of Emergency Management, Vol. 11, No. 1, pp.62-75.

Reilly, T. (2001) 'Collaboration in action: an uncertain process', Administration in Social Work, Vol. 25, No. 1, pp.53-74.

Rosenthal, U., Boin, R.A. and Comfort, L. (Eds.): (1999) Managing Crises: Threats, Dilemmas, Opportunities, Charles C. Thomas, Springfield.

Royal Canadian Mounted Police (RCMP) (2012) Public Interest Investigation into RCMP Member Conduct Related to the 2010 G8 and G20 Summits, Retrieved 5 May, 2015, from http://www.crcc-ccetp.gc.ca/pdf/g8g20R-eng.pdf

Royal Canadian Mounted Police (RCMP) (2014) 2010 G8 and G20 Summits RCMP led Horizontal Evaluation Report, January, Retrieved 5 May, 2015, from http://www.rcmp-grc.gc.ca/audver/reports-rapports/G8-G20-eng.htm\#Findings

Smith, D. (2000) 'Crisis management teams: issues in the management of operational crises', Risk Management, Vol. 2, No. 3, pp.61-78.

Statens Offentliga Utredningar (SOU) (2002) Händelserna i samband med Europeiska rådets möte $i$ Göteborg den 14-16 juni (2001).

The Toronto Star (2010) Advice Ignored on G 20: Ottawa Moved Summit from Exhibition Place to Downtown over Toronto's Objections, Mayor Says, 30 June.

Torcal, M., Rodon, T. and Hierro, M.J. (2016) 'Word on the street: the persistence of leftistdominated protest in Europe', West European Politics, Vol. 39, No., 2, pp.326-350.

Toronto Police Service (2011) Toronto Police Service After-Action Review, Retrieved 14 December, 2017, from http://www.torontopolice.on.ca/publications/files/reports/g20 after_action_review.pdf

Van den Berg, M. and Westerbeek, P. (2014) 'Balanceren op de rode lijn', Magazine Nationale Veiligheid en Crisisbeheersing, Vol. 2, pp.7-8.

Wallmann, F. (2006) Ordningensdynamik-En jämförelse av demonstrationerna i Prag, Nice, Göteborg och Genua, CRISMART.

\section{Notes}

${ }^{1}$ The authors would like to thank Fredrik Bynander, Daniel Nohrstedt, Arjen Boin, Paul 't Hart and two anonymous reviewers for their constructive comments, our interview respondents In The Netherlands and Canada for sharing their time and experience, and the Swedish Civil Contingencies Agency (MSB) for their recognition of the importance of the theme collaborative crisis governance and for their generous project funding. 
${ }^{2}$ More specifically: the IMF annual meeting, September 2000 in Prague, the European Council meeting in Nice, December 2000 and the EU Finance Council, April 2001, in Malmö.

${ }^{3} \mathrm{http} / / /$ www.thestar.com/news/gta/g20/2010/06/26/violent_black_bloc_tactics_on_display_at_g20_ protest.html

${ }^{4} \mathrm{http}: / /$ www.theglobeandmail.com/news/world/a-history-of-summitprotest/article $4084135 /$ from $=4323163$

${ }^{5}$ In addition to the Royal Canadian Mounted Police (RMCP), these were the Peel Regional Police (PRP), the Ontario Provincial Police (OPP) ${ }^{1}$, the Canadian Forces (CF) and Toronto Police service (TPS).

${ }^{6}$ Within the controlled access and restricted access zone

${ }^{7}$ See Bestuurlijke rapportage verloop NSS Den Haag, 25-04-2014, The Hague City. A total number of 75 related NSS arrests were made, of which 63 were related to public order disturbances. All people arrested were released the same day.

${ }^{8} \mathrm{~A}$ long range acoustic device (LRAD) is a hailing device that sends loud warning tones over longer distances, in this case, deployed to prevent people from standing close to the fences around the secured zone. 